\title{
Is lower intensity aquaculture a valuable means of producing food? An evaluation of its effects on near-shore and inland waters
}

James S. Diana

School of Natural Resources and Environment, University of Michigan, Ann Arbor, MI, USA

\section{Correspondence}

James S. Diana, School of Natural Resources and Environment, University of Michigan, 440 Church Street, Ann Arbor, Ml 48109-1041, USA.

Email: jimd@umich.edu

Received 30 November 2011; accepted 19 May 2012.

\begin{abstract}
The effects of aquaculture on the environment have been the subject of much examination, but most of the focus has been on shrimp and salmon. These are not the most common species grown in aquaculture, nor the most common systems used. About $60 \%$ of production today uses lower intensity culture to produce organisms in natural systems such as ponds. This paper is an overview of the positive and negative environmental impacts of lower intensity aquaculture. The ranked positive impacts of lower intensity aquaculture include: conservation aquaculture that supplements reproduction in natural populations; improving the quality of natural waters through filtering or consuming wastes by cultured organisms; reducing pressure on wild stocks by providing alternative sources in the market; and replacing damaging employment with more sustainable aquaculture jobs. Negative impacts include: escapement of alien species that become invasive; eutrophication of receiving waters from pond effluents; release of parasites and diseases into natural communities; escapement of unique genotypes resulting in genetic alteration of native stocks; land degradation due to pond construction; release of antibiotics or other drugs into receiving waters; depletion of natural resources such as water; loss of benthic biodiversity from settling of sediments; and reductions in natural populations by collection of larval or juvenile fish. Some impacts, especially the use of fishmeal and the transmission of disease, are much less common in lower intensity aquaculture systems. Aquaculture has an important role in current and future food production, and in many cases lower intensity aquaculture provides a sustainable solution to increased aquaculture production.
\end{abstract}

Key words: aquatic conservation, environmental impacts, food production, lower intensity aquaculture.

\section{Introduction}

Human population growth continues, and forecasts indicate a global population of about 8.9 billion in 2050 (Cohen 2003). This increase of nearly 3 billion since 2005 will require $70 \%$ more food production to feed the increased population as well as adequately to feed people who are currently underfed or eat nutritionally deficient diets (FAO 2009). While seafood is only responsible for a small fraction of today's global caloric consumption, it is an important animal crop with high protein content and other nutritional advantages. Aquaculture is the main increasing sector for seafood production and the fastest growing of all food commodities, with an average growth rate of around 9\% since 1985 (Diana 2009). The future role of aquaculture in feeding the hungry is controversial, as some see aquaculture as a polluting and environmentally degrading food production method (Naylor et al. 2000; Ford \& Myers 2008), while others see it as an efficient, expanding and important means to produce more food in a relatively sustainable manner (Duarte et al. 2009; Costa-Pierce 2010). The purpose of this overview is to evaluate the positive and negative aspects of lower intensity aquaculture, as an introduction to the series of 
publications resulting from a symposium held at the annual meeting of the American Fisheries Society in September 2011. The papers that follow will provide richer details on many of these effects.

Aquaculture systems vary in the types of containment used, effluent produced and inputs required (Pillay 1993; Lucas \& Southgate 2012). Aquaculture has been categorized into extensive, semi-intensive and intensive methods based on inputs and stocking densities, with intensive methods relying completely on formulated feeds and organisms stocked at high densities, semi-intensive relying on fertilizers or nutritionally incomplete fodders and organisms at moderate densities, and extensive relying on natural production and organisms at low density. The boundaries between these types are not well defined; here the focus will be on extensive and semi-intensive aquaculture (henceforth termed lower intensity aquaculture). These are defined as systems that do not rely on formulated diets at high input rates to completely feed the crop (Appleford et al. 2012). Much of the criticism of aquaculture has been directed at very intensive systems such as shrimp culture in ponds or salmon culture in cages (Naylor et al. 1998). However, most global production in aquaculture comes from less intensive means, although direct statistics on proportions are lacking. Costa-Pierce (2010) estimated that only $40 \%$ of annual production was derived from aquaculture that used formulated feeds. Verdegem and Bosma (2009) estimated the global average aquaculture production in 2004 derived from ponds alone to be 25.3 million tonnes (MT), representing $56 \%$ of the 45.5 MT produced that year (FAO 2010a). They also estimated the average production levels for these ponds were from $3000 \mathrm{~kg} / \mathrm{ha}$ in freshwater to $7530 \mathrm{~kg} / \mathrm{ha}$ in brackish water in China, also indicative of lower intensity systems. Both of these estimates demonstrate that lower intensity production is a common method of aquaculture today.

There remains additional controversy among proponents of aquaculture expansion on the best type of system that should be developed to meet future demands. If one bases the best type on degree of land use or production per unit area, intensive systems should be developed for future needs (Marra 2005; Duarte et al. 2009). However, if one evaluates best type on effects of the system on receiving waters, or energy demand of the crop, then lower intensity systems should be developed (Diana 2009; Costa-Pierce 2010; Cao et al. 2011). Of course, both of these extrapolations depend on the kind of aquaculture practised; for example, zero-exchange recirculating systems are intensive but produce no effluents (Piedrahita 2003). Both high and lower intensity production will likely be necessary and important in the future, and the environmental performance of each can be improved.
Many less intensive systems provide an opportunity to produce food mainly for household consumption, and possibly for some income (Diana 2009; Hall et al. 2010). Thus, lower intensity systems have importance beyond the absolute quantity of crop produced, as they also help to solve some poverty and food security issues. A good way to help in poverty reduction, food security and the environment is to consider current systems utilized by small-scale farmers and to do research and extension on those systems so the most sustainable and profitable practices can be encouraged. Development projects have often failed because they do not consider the role of local people, or the beliefs and social constraints that affect the adoption of new systems (Rogers 1995; Schwantes et al. 2009). A far better means of intervention is to consider the small-scale systems already in place in various locations (which are mainly lower intensity), and to help develop more sustainable practices for those systems.

Aquaculture results in the production of high quality food. This seems obvious, yet many times we ignore that the increased production of food is not a luxury but a necessity. Food production itself produces major environmental impacts (Tilman et al. 2009), including land conversion with over $70 \%$ of grassland habitat and $50 \%$ of savannah converted for agriculture (Foley et al. 2011). Lower intensity aquaculture is a valuable means to use natural ecological processes to aid in food production, since it does not rely entirely on formulated feeds but often uses waste crops, other available fodder and fertilizer to stimulate natural processes in ponds and to produce a crop. Another form of this aquaculture is even more benign; that is, to use bivalves or seaweed in natural waters to not only grow a crop with minimum human inputs but also to improve water quality in the process. It is difficult to directly compare the efficiency of different food production systems, because the metrics have not been commonly studied and rely on the scope of the study (for example, comparing just energy used in farming or energy used throughout the entire life cycle of feed and fertilizer production) as well as local variations in farming systems. However, Table 1 shows that lower intensity aquaculture is as efficient as chicken production and better than all other forms of meat production (see also Costa-Pierce 2010). Aquaculture is a form of food production and its environmental impacts should be compared with other forms of food production, not with natural ecosystems and their functions (Diana 2009; Costa-Pierce 2010).

Over $75 \%$ of seafood produced in developing countries is consumed locally, indicating that seafood fulfills a special role in expanding food security for the world's poor (Hall et al. 2010). In the face of population growth and climate change, there is considerable concern about the 
Table 1 Values for production efficiency in aquaculture (ranked with lowest intensity systems at the top) and other food crops

\begin{tabular}{|c|c|c|c|c|}
\hline Product & $\begin{array}{c}\text { Edible } \\
\text { FCR }\end{array}$ & $\begin{array}{c}\text { Energy to } \\
\text { protein } \\
\text { efficiency }\end{array}$ & $\begin{array}{c}\text { Energy } \\
\text { efficiency }\end{array}$ & $\begin{array}{c}\text { Edible } \\
\text { proteir } \\
\text { EROI }\end{array}$ \\
\hline \multicolumn{5}{|l|}{ Aquaculture } \\
\hline Tilapia & 2.5 & 8 & & 0.07 \\
\hline FW prawns & 4.4 & & 6.6 & \\
\hline Catfish & 2.5 & $25-34$ & & 0.03 \\
\hline Marine shrimp & 4.5 & $40-70$ & 45.6 & 0.01 \\
\hline \multicolumn{5}{|l|}{ Other crops } \\
\hline Milk & 3 & 14 & & 0.07 \\
\hline Eggs & 3.1 & 26 & & 0.04 \\
\hline Chickens & 3.1 & $22-34$ & 55 & 0.03 \\
\hline Swine & 5.6 & 35 & $16-22$ & \\
\hline Beef & 10.2 & 10 (range) - 78 (feedlot) & 40 & 0.02 \\
\hline Lamb & 17.4 & 10 & & 0.02 \\
\hline
\end{tabular}

Edible FCR is $\mathrm{kg}$ dry feed input per $\mathrm{kg}$ edible wet mass output [from Costa-Pierce (2010)]; energy to protein efficiency is fossil fuel energy input in kcal to protein output in kcal [also from Costa-Pierce (2010)]; energy efficiency is $\mathrm{Mj}$ of energy input to $\mathrm{kg}$ output [from Mungkung \& Gheewala (2007)]; and edible protein energy return on investment (EROI) is the edible protein output in J per fuel energy input in J [from Tyedmers (2001)]. For all efficiencies except EROI, lower numbers indicate better efficiency.

needs for high quality protein in the diets of millions of the world's poor (Smil 2002). Seafood produced by aquaculture may have an especially important role in meeting this protein demand in the developing world (De Silva \& Soto 2009; Rice \& Garcia 2011).

Numerous authors have evaluated aquaculture and its expansion and have produced rankings of various positive and negative effects of aquaculture on the environment (Egna \& Boyd 1997; Boyd 2003; Boyd et al. 2005; Diana 2009; Duarte et al. 2009; Costa-Pierce 2010; FAO 2010b). These categories include both direct effects, such as the release of invasive fish into natural waters or the eutrophication of waters, and indirect effects, including water and energy use or changes in the means of livelihood for local people. A ranking of the positive environmental impacts of lower intensity aquaculture presented here includes: (i) conservation aquaculture, which is mainly supplementing reproduction in natural populations where recruitment is limited; (ii) improving the quality of natural waters by filtering or consuming of materials done by cultured organisms; (iii) reducing the pressure on wild stocks by providing alternative sources to the market; and (iv) replacing more damaging forms of employment with more sustainable aquaculture jobs. The ranking of the nine negative impacts that are important includes: (i) escapement of alien species that become invasive; (ii) eutrophication of receiving waters from pond effluents; (iii) release of parasites and diseases into natural communities; (iv) escapement of native species with unique genotypes resulting in genetic alteration of natural stocks; (v) land degradation due to pond construction; (vi) release of antibiotics or other drugs into receiving waters; (vii) depletion of natural resources such as water and fishmeal; (viii) loss of benthic biodiversity from settling of sediments produced in the culture system; and (ix) reductions of natural populations by collection of larval or juvenile fish. The purpose of our symposium was to provide an unbiased evaluation of these various effects. My objective here is to use a review of the literature to briefly evaluate each of these potential effects of aquaculture.

\section{Positive effects}

There have been numerous publications dealing with the negative effects of aquaculture, so I will start off with positive effects in order to develop a different train of thought. The first positive effect of aquaculture is conservation aquaculture, used in the reseeding of declining natural populations of aquatic organisms. This role has been recognized for hundreds of years, and many government agencies have used fish hatcheries to produce and stock fish into natural waters for various purposes (Halverson 2008). While much of this stocking has been done to improve sport fish or commercial fish production, some has focused on restoration of declining stocks (CostaPierce \& Bridger 2002). For example, the culture of giant clams (Tridacna spp.) resulted in animals that were used for consumption, for products made from the shells, and for restocking natural populations (Bell 1999). While this programme had lofty goals for giant clam restoration, it did not achieve the desired increases in clam populations due to limited adoption by private citizens in the Pacific islands. Another programme demonstrating better success was for white sturgeon (Acipenser transmontanus) in the Kootenai River, USA and Canada (Ireland et al. 2002). Here government organizations established a programme to rear sturgeon in captivity focused on supplementing this endangered fish population. This programme has had success, with 398 fish recaptured later, representing 15\% of those originally stocked (Ireland et al. 2002). Throughout the world there are hatcheries geared to produce threatened and endangered species for reseeding populations (Anders 1999). Since many of these species will not readily take to artificial feeds, they are often grown in lower intensity systems, where natural foods or nutrients are promoted.

The second positive effect is the cleaning of waters that occurs by consumption of waste materials done by cultured organisms. Such systems have been applied to 
cleaning up wastes generated by agriculture, sewage discharge and aquaculture effluents. Use of aquatic organisms to consume dense concentrations of phytoplankton, zooplankton and suspended particles in aquaculture ponds is a well known and ancient method, stemming back to polyculture techniques in ancient China, Polynesia and elsewhere (Costa-Pierce 2010). Integrated multi trophic aquaculture has been advanced to absorb mariculture discharges into marine systems, using seaweeds and bivalves to intercept nutrients and particles released from nearby intensive aquaculture cages, reducing the effluent effects of the cages on local water quality (Neori et al. 2004; Troell et al. 2009). These seaweed and bivalve crops may be contained in the cage operation itself or in nearby waters.

Beyond the improvement of aquaculture effluents, lower intensity culture is also used commonly as a biomanipulation to remediate damages caused in natural systems by other human induced inputs of nutrients and materials. An improvement in water quality often occurs as a result of culturing bivalves and seaweeds in natural waters that have been degraded (Neori et al. 2004; Xiao et al. 2007; Sequeira et al. 2008). Bivalve culture is commonly used as a habitat restoration method in polluted bays and, depending on the circumstances, can be a successful means to reduce pollution effects. For example, Sequeira et al. (2008) evaluated the filtering capacity of shellfish in reducing eutrophication of four bays, and found that filterers cleared from $5 \%$ to $45 \%$ of the bays' volumes daily. They also found strong competition between wild and cultured species of shellfish, so the success of such biomanipulations may depend on the natural communities already present in a bay. Xiao et al. (2007) found similar results in Chinese waters, while Miron et al. (2005) and Crawford et al. (2003) found minimal positive (but no negative) effects of shellfish culture in reducing the productivity of other natural bays. Zhou et al. (2006) and Yang et al. (2006) both described the common method of seaweed culture in China, which takes advantage of rich nutrient supplies in coastal waters and results in significant removal of nutrients by seaweeds. These biomanipulations, while not always successful, are important because they not only improve habitat but also produce a valuable crop for human consumption, animal feeds or other uses.

The third positive effect of aquaculture on biodiversity is reducing pressure on wild stocks by providing alternative sources of that product in the market. In the 1980s, it was commonly believed that aquaculture could not compete in the market place with a wild fish crop, so that aquaculture only expanded into areas with small wild harvests or where harvests declined due to overfishing. However, in more recent years the development of aquaculture for common commercial species such as Pacific salmon and shrimp has changed this paradigm. Diana (2009) provided evidence that when cultured Atlantic salmon (Salmo salar) increased in production, wild fish harvests declined and natural populations rebounded. This demonstrates replacing the wild crop in the marketplace with cultured fish, with a decline on harvest pressure for wild stocks and the potential for restoration of natural populations. For species grown in lower intensity systems, there are also a number of examples of replacement and expansion trends in wild and cultured species (Fig. 1). For all four of the selected species, aquaculture grew dramatically from 1950 to the present and exceeded capture fisheries in yield. In all cases, the market is now dominated by cultured products. For snakeskin gourami (Trichogaster pectoralis) and the seaweed Laminaria, capture fisheries declined to near zero after culture expanded, while for Nile tilapia (Oreochromis niloticus) and scallops, a substantial but much lower capture fishery persisted after the development of aquaculture [data from FAO (2010a)]. Of course, this simple analysis does not evaluate whether the capture harvests are sustainable or whether the replacements in the market have enhanced wild populations by reducing pressure on these species, but it at least indicates that the markets are changing as a result of lower intensity aquaculture.

The fourth positive role of aquaculture is replacing damaging forms of employment with more sustainable aquaculture jobs. This is a double-edge sword, as at times aquaculture interferes with local artisanal fishing, which can be sustainable employment. However, artisanal fishing is also suffering greatly from overfishing and competition with offshore commercial fishing in marine environments (Heck et al. 2007; Hall et al. 2010). Aquaculture employment in many parts of the world can be more lucrative (Schwantes et al. 2009), long-term and safer than many other rural jobs for poor people (Pomeroy et al. 2006b).

Pomeroy et al. (2007) presented a particularly troubling case of 'fish wars' that developed after overfishing resulted in low yields and much competition for capture fisheries in Southeast Asia. Replacement of capture fisheries by aquaculture, either in overexploited situations or in situations where exploitation is harming natural biodiversity, can result in net benefits to both the local community and to biodiversity. For example, Pomeroy et al. (2006a) evaluated the replacement of harmful fishing with aquaculture for coral reef species, and while he found many challenges to this conversion, conversions had occurred. Similarly, Pollnac et al. (2001) found that many fishers in poor communities in Vietnam wanted to convert to aquaculture as a means of better living, and this would also reduce fishing pressure on overfished stocks. Even beyond the fishing trades, small-scale aquaculture may 

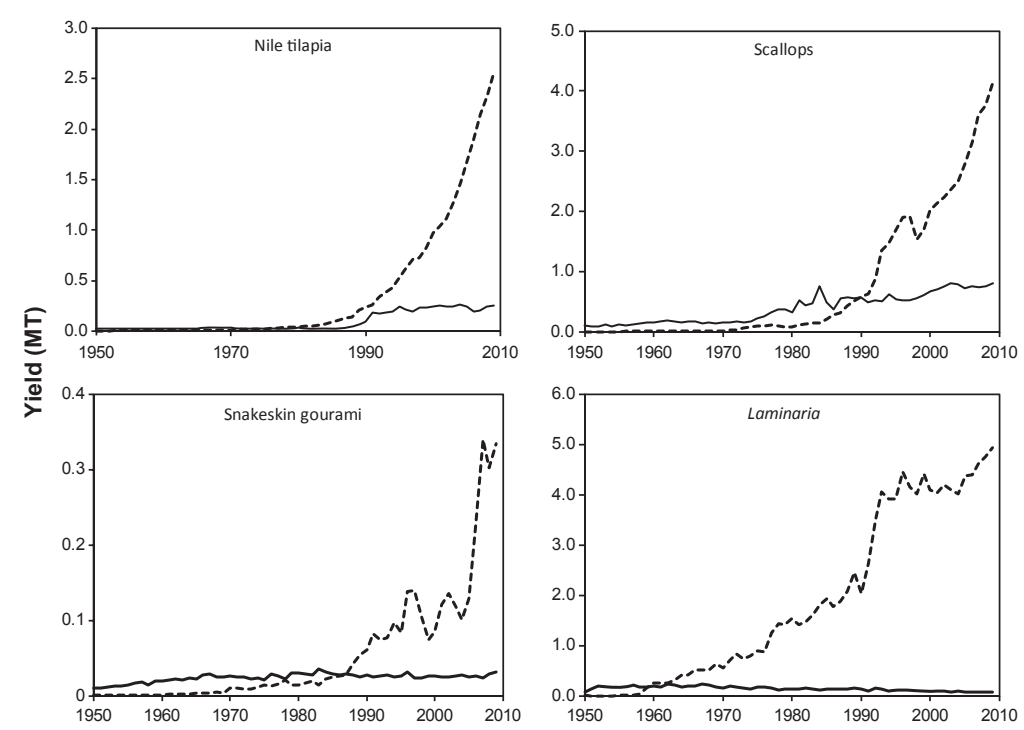

Figure 1 Changes in capture harvest and culture yield for four species that are cultured at lower intensity. The upper graphs demonstrate species where the wild harvest continued at a stable level after aquaculture expanded dramatically, while the lower two demonstrate species where the harvest declined to near zero after aquaculture expansion All four demonstrate market replacement from captured to cultured organisms. (- - -) Culture; (-) capture.

provide a safer and less damaging income than slash-andburn agriculture (Jones et al. 2007) or many rural and urban jobs (Singh \& Dey 2010), and as such can provide security to humans as well as less damaging activities than would exist without aquaculture. Examples of the use of aquaculture to enhance human job security and safe employment include the work of many NGOs such as Caritas in Bangladesh and Nepal to provide aquaculture training and outreach to help produce better and more sustainable livelihoods for the rural poor (Diana 2009). Costa-Pierce (2010) showed that aquaculture not only provided jobs for people working on farms, but more employment was generated in processing and marketing the fish produced than in the original farming jobs.

\section{Negative effects}

There are also a number of negative impacts that lower intensity aquaculture has had on the environment. Once again, it is important to put these into context, compared with other stressors, particularly agriculture. The first and most important of these negative effects is escapement of alien species that become invasive. Many people consider Asian carps and tilapia to be prime examples of invasive aquatic species, and both were largely introduced throughout the world for aquaculture production. In fact, up to $90 \%$ of the yield for the 22 species of freshwater finfish that produce over 10000 tons in aquaculture annually is from alien species, and $16 \%$ of global aquaculture production results from alien species used in production (De Silva et al. 2009). De Silva et al. (2009) evaluated the documented cases of harm from tilapia introductions and acknowledged that many cases were not well documented as to the end result of alien species release into natural waters. There were 349 cases of known releases, 17 with adverse ecological impacts, 13 with beneficial, and the remainder with an unknown effect. They proposed that fresh introductions of alien species should not occur in aquaculture development, and indigenous species would be better candidates for aquaculture expansion into new locations. There is not consensus on the promotion of indigenous species in aquaculture, as the FAO (2008) also considers genetic improvement and domestication as a good means of aquaculture development. This focus on indigenous species also contradicts the history of agriculture, where few strains or species of animals were developed in domestication, and they are used nearly universally.

The case history of tilapia as an alien and invasive species is sobering, as many documented cases of damage have resulted from tilapia introductions (Canonico et al. 2005; De Silva et al. 2009). Aquaculture has played a role in this, although more than half of the documented introductions of tilapia were not the result of commercial aquaculture but of intentional stocking of tilapia in natural waters by governmental entities (Canonico et al. 2005). Peterson et al. (2005) determined that tilapia were the sixth most common species collected in their study in Mississippi watersheds. They also found that both aquaculture operations and power plant effluents were 
common contributors to the tilapia invasion, providing sources for recolonization and thermal refuges. While Peterson et al. (2005) did not quantify the reductions in other species in these receiving waters due to the spread of tilapia, there are numerous other studies that have documented changes in systems after expansion of tilapia, including the loss of submerged aquatic vegetation and changes in the abundance and distribution of native fishes present (Eglund 2002; McCrary et al. 2005). The causes of damage due to these introductions are difficult to quantify, as often multiple human disturbances have occurred at the same time as the introduction. Many of the sites dominated by tilapia are altered habitats where modification has interfered with the development of natural fish communities and facilitates the expansion of exotic organisms (Moyle \& Light 1996; Peterson et al. 2005). Initial introduction is not the only concern, as aquaculture facilities are linked to the spread of tilapia to new watersheds in a region as well as their continuance in those watersheds (De Silva et al. 2009; Esselman 2009). The FAO (2008) promoted a precautionary approach to alterations in genetic resources, which states 'where there are threats of serious or irreversible damage, lack of full scientific certainty shall not be used as a reason for postponing cost-effective measures to prevent environmental degradation'. This approach urges a balance that focuses on natural ecosystems as well as human developmental needs. Such an approach is the least that should occur when considering new introductions of non-native species, while stricter bans on these introductions should also be considered (De Silva et al. 2009; Diana 2009).

The second negative impact of lower intensity aquaculture is eutrophication of receiving waters from farm effluents. This impact includes mainly effluents from ponds, as seaweed or mollusc culture in the nearshore environment rarely causes water quality problems. Lower intensity pond systems produce effluents that can have effects on receiving waters (Boyd 2003). Most ponds using lower intensity aquaculture do not have a regular exchange of water, because that would result in a loss of the nutrients used to drive production. However, most still discharge water during precipitation events, flooding or harvest (Boyd 2003). The discharge of nutrients, suspended solids and other materials at harvest can be a major impact of aquaculture, and commonly results in the eutrophication of receiving water bodies (Trott \& Alongi 2000; MacKinnon et al. 2002). While studies on effluents from lower intensity systems may not have demonstrated effects on biodiversity of receiving waters, there are numerous studies on eutrophication demonstrating significant losses of intolerant species and shifts in dominant species due to eutrophication (Agostinho et al. 2005; Gong \& Xie 2011). There are also a number of studies evaluating how to remediate effluent effects through water treatment in ponds, drainage into settling ponds and harvest methods (Boyd 2003; Lin \& Yi 2003). Governments are moving to regulate and enforce effluent standards in all forms of aquaculture (Boyd 2003), based on the general knowledge of eutrophication effects and the methods available to reduce the impact of pond effluents.

The third negative impact is the release of parasites and diseases into natural communities. For intensive systems, this has been the subject of much debate in the salmon-sea lice issue (Krkosek et al. 2007; Brooks \& Jones 2008). One example of this issue for lower intensity aquaculture is the spread of Koi herpes virus from the ornamental fish trade to common carp (Cyprinus carpio) aquaculture, then to wild carp populations (Bondad-Reantaso et al. 2005). If water from diseased aquaculture facilities is exchanged with natural waters, disease organisms will be introduced into natural waters, and their spread will depend on local conditions (Bondad-Reantaso et al. 2005). Another example of disease spread caused by lower intensity aquaculture is the mass mortality of oysters and crayfish that occurred with the importation of new species from the Pacific and America (Murray \& Peeler 2005). The disease problem in aquaculture has led to management developments such as the use of specific pathogen free (SPF) organisms and antibiotics. Antibiotic release is a concern that will be covered later. The SPF brood stock has revolutionized the shrimp industry, with the changeover from Penaeus monodon to Litopenaeus vannamei occurring once SPF broodstock of the latter species became available (Lightner 2005). The term SPF indicates organisms that have been reared in pathogenfree conditions for certain diseases, so the starting point of a brood stock is to produce young that will initially be pathogen-free. However, these organisms are no more resistant to pathogens in the culture system than any other organisms, so clean culture is still required. So far the widespread use of SPF broodstock is limited to the shrimp industry, but SPF individuals of a variety of fish species have been used in many hatchery cases to replace diseased brood stock when a particular outbreak occurred (Amend 1976), and the development of SPF broodstock of other species could occur if disease outbreaks became major issues (Bondad-Reantaso 2007).

The fourth negative impact is escapement of native species resulting in genetic alteration of natural stocks. The genetic effects of escaped organisms on natural species have been emphasized in salmon culture, particularly Atlantic salmon (Fleming et al. 2000). Similar concerns have been expressed for a variety of marine finfish (Youngson et al. 2001), salmonids (Hiundar et al. 1991) and clams (Kong \& Li 2007), to name a few. This leads to a controversy (Bartley et al. 2009) that some culturists would prefer to 
see strong selection for faster growing and more disease resistant strains of aquatic species, while others prefer less domestication and the use of native or sterile fish for culture purposes. Most genetic selection for improved growth and food utilization has occurred in intensively produced fish (Hulata 2001), although the historic domestication of carps and the current development of GIFT tilapia are examples of this process for lower intensity culture (Ponzoni et al. 2005). Some aquaculturists are currently calling for the culture of locally existing organisms (De Silva \& Soto 2009; Diana 2009), while others desire better domestication, genetic selection and even genetic modification (Hulata 2001; FAO 2008; Bartley et al. 2009).

The fifth negative effect is land degradation due to pond construction. There is an obvious link between the clearing of land for human purposes and the loss of biodiversity, most commonly expressed in the species-area curve. In freshwater systems, virtually all lower intensity aquaculture is done in ponds. With their lower level of production, these ponds take up much more space to produce the same biomass of crop compared with cages or intensive ponds. Land conversion for human food production is a global issue today, with over $25 \%$ of the earth's surface (33 million square $\mathrm{km}$ ) cleared as grazing lands for meat and milk production (Asner et al. 2004). In comparison, estimates of land cleared for pond culture (11 100000 ha or $111000 \mathrm{~km}^{2}$, Verdegem \& Bosma 2009 ) is only about $0.3 \%$ of the land used in meat production. Comparing land clearing for these two purposes, even considering the difference in total production, can at least be estimated in simple calculations. Pond aquaculture production (mainly semi-intensive) was about 25.3 MT in 2008, while meat and milk production about $863 \mathrm{MT}$, so the fraction of pond-produced seafood to meat was $2.9 \%$. However, given the production levels and land use for each pursuit, pond aquaculture produced nine times more mass of crop than meat and milk on a hectare of land. This also assumes that all meat and milk was grown on range land, which of course is not the case, so it makes the meat value higher than actual. Such an analysis discounts the quality of the land used in each conversion, which may be prime agricultural areas, coastal sites or wetland habitats of value in the water cycle. Another land-use issue in aquaculture is the construction and abandonment of ponds, especially in the case of marine or brackish water systems, where the soils are damaged and may not be immediately useful for other agricultural pursuits (Naylor et al. 1998). While pond abandonment is an issue (Barbier \& Cox 2004), particularly in areas where animal diseases become established, the reuse of those ponds is also common and in the longer term most pond areas are reclaimed and used in aquaculture or other human pursuits (Clark 2003).
The conversion of mangroves to ponds is a special problem here (Flaherty \& Karnjanakesorn 1995). While the cases that have been made are mainly on shrimp aquaculture, comparable issues arise in lower intensity culture of milkfish (Kuhlmann et al. 2009). Mangroves are important nursery areas for fish and marine shrimp, and as such they also support a significant harvest in nearby waters. de Graaf and Xuan (1998) determined that 1 ha of mangrove in Vietnam supported approximately $450 \mathrm{~kg}$ of marine fishery harvest, while others estimated this value at 100-1000 kg (Turner 1977; Lal 1990; Hambrey 1996). Overall, land conversion and degradation occurs in aquaculture, but not as extensively or any more damaging in general than land conversion for agriculture or urban growth, and both of those uses have converted much more land than aquaculture.

The sixth negative impact is release of antibiotics or other drugs into receiving waters. This has been a major concern in intensive culture, where studies of sediments near culture facilities often show elevated chemotherapy agents (Lalumera et al. 2004). Antibiotic use is an important issue in fed aquaculture, where it can be administered in feeds (Burridge et al. 2010). Its use in non-fed systems is much less but still present. Major concerns are for human health, but these materials also can have significant effects on fish and invertebrates as well. These effects include the emergence of antibiotic-resistant bacteria in aquaculture areas, an increase in antibiotic resistance in fish pathogens, the transfer of resistance to bacterial pathogens of land animals and humans, and the alteration of the bacterial communities of sediments and receiving waters (Cabello 2006). In many countries, antibiotics are banned or strictly limited for aquaculture production, but these guidelines are not often followed. It is a major impact of aquaculture, and agriculture for that matter, and is the target of a number of regulations and best practices. While there is a strong opinion that the use of antibiotics in aquaculture should be avoided and regulated, this is not the case in all producing countries (Burridge et al. 2010). Such management techniques as improved sanitation in the culture system, development of vaccines, improved water quality and treatment of aquaculture discharges in settling ponds or other facilities are all alternative methods of disease control, which are very effective and should be used (Cabello 2006).

The seventh negative impact is a reduction of natural resources including water and fishmeal species. While the biggest issue in water use is related to the scarcity of water and its need for human quality of life (Radulovich 2011), there are also clear implications on the environment when water is removed from surface sources, especially in arid climates (Verdegem \& Bosma 2009). Since lower intensity systems generally do not use large volumes 
of formulated feeds with a high fishmeal content, the lack of fishmeal depletion can be considered a benefit of lower intensity farming for most species. However, water use remains a major natural resource sink that is important in lower intensity aquaculture. Verdegem and Bosma (2009) did an excellent analysis of water use in pond aquaculture. The details of water use are system specific and too complex to evaluate completely here. Average global water use in freshwater aquaculture is $16.9 \mathrm{~m}^{3} / \mathrm{kg}$ of production, with $30 \%$ going to evaporation, $40 \%$ to seepage, $10 \%$ to feed production and $18 \%$ to discharge (Verdegem \& Bosma 2009). Current water use in aquaculture is more on a per $\mathrm{kg}$ basis for freshwater fish from ponds (16.9) than for beef (8.4, Verdegem et al. 2006). However, intensive and recirculating systems for fish use water in amounts similar to beef or even better. The actual ratio depends greatly on the quality of water discharged from ponds at harvest (Verdegem et al. 2006), because seepage and discharge water are returned to natural systems and may not be degraded if water quality is maintained. Mariculture uses water only based on water needed for food ingredient production, which means seaweed culture is water neutral (Radulovich 2011), but cage culture of animals is fed and uses about $2.9 \mathrm{~m}^{3}$ of water per $\mathrm{kg}$ produced. Finally, brackish water culture has high water demands, as the mixture of fresh and salt water means that none of the discharge can be returned to productive use on the land. Verdegem and Bosma (2009) evaluated options for lower intensity ponds and determined that lower flushing rates and feeding rates, using feed ingredients with lower water demand, or not feeding at all resulted in less water use. Their final recommendations also included paying better attention to water quality in ponds, improving management practices to produce more yield in the same quantity and quality of water, and reducing dependence on water intensive grains in feed. All of these should be components of well-managed aquaculture systems for the future.

The eighth negative effect is the loss of benthic biodiversity from settling of sediments produced in the culture system. Once again the main criticism for this effect has been related to net pen culture of salmonids (Brooks et al. 2003) as well as other fish cages (Dimitriadis \& Koutsoubas 2011). However, sediments are a common constituent of pond discharges, and the settling of suspended sediments in natural waters results in a loss of benthic organisms in areas where currents do not eliminate sediment accumulation (Longdill et al. 2007). Similar issues occur due to the production of pseudofaeces in oyster culture. Here again some perspective is in order. The major factor causing such settlement of sediments and anaerobic deep waters in coastal environments is land-based agriculture and overuse of nitrogen fertilizers
(Rabalais et al. 2002). The area of dead zones globally exceeded $245000 \mathrm{~km}^{2}$ in 2006, which is well in excess of any estimates for potential smothering caused by aquaculture. However, this lower damage compared with agriculture does not excuse aquaculture to discharge sediments because it is not the major polluter. Earlier cited studies on bivalves (Crawford et al. 2003; Miron et al. 2005) demonstrated varying sediment accumulation below these culture systems, and studies of intensive fish production produced more dramatic effects (Brooks et al. 2003; Dimitriadis \& Koutsoubas 2011). Pond aquaculture should treat discharges with sediment basins (Boyd 2003) and bivalve culture should reduce stocking densities in an area (Crawford et al. 2003) or use integrated culture with detritivores such as sea cucumbers (Ahlgren 1998) to reduce local sedimentation effects.

The final negative interaction is collection of larval or juvenile fish from natural populations. This can reduce the abundance of natural populations, leading to reduced yield from wild fisheries or even recruitment failure (Cicotti 2005) and high mortality rates in species incidentally collected with the target organism (Bhattacharya \& Sarkar 2003). Collection of wild seed is particularly important in lower intensity aquaculture because artificial reproduction and control of the entire life cycle is usually necessary for most types of intensive culture (Stickney 1993), with the notable exception for some types of shrimp (Azad et al. 2009). As aquaculture has progressed, methods have been developed artificially to produce young of most species under controlled conditions, making the need for wild seed collection relatively rare. This is not necessarily true for new or indigenous species, or in some developing countries (Primavera 2006), so closing the life cycle to permit hatchery production of seed should be a first priority in the culture of a new species.

\section{The future}

Considering all of the positive and negative impacts above, should we promote lower intensity aquaculture in the future? Such a decision requires a synthesis of all the positive and negative effects listed above and the consideration of the need for food in the future. For most systems, more limited alteration of water quality and the limited use of fishmeal in formulated feeds allow lower intensity aquaculture to avoid many of the major pitfalls of intensive methods. When compared with most terrestrial agriculture, it produces protein-rich food more efficiently in terms of energy inputs, food conversion and land area affected. While it may have significant negative environmental impacts, many of those impacts can be improved with research and extension of new systems including the culture of indigenous species from the 
Amazon such as Tambaqui (Colossoma macroponum) (Gomes \& Silva 2009), particularly since Tambaqui are herbivorous and can feed on waste fruits and vegetation.

For lower intensity aquaculture to really flourish, more systems need to be developed using indigenous species from low trophic levels that produce crops using natural processes that can be enhanced by management. In addition, we should expand the use of bivalves and seaweeds to remediate intensive aquaculture wastes as well as to remediate pollution in bays and other coastal waters. This relies on the produced bivalves and seaweed having an expanded market so the additional crop can be sold and used in products such as animal feed, compost for land crops, or algal products that have economic value. These are win-win situations, where pollution problems are cleaned up and a valuable crop is also produced.

We need to expand food availability over the next 40 years, most likely by increasing most means of food production. Much production by lower intensity aquaculture comes from small-scale local systems used in the developing world, and those systems are expanding. Aquaculture has a special role in local food security in these areas. The research community should help developing countries expand their food production and income generating capacity, and the best means of doing that is to do research and extension on existing production systems so the most sustainable and profitable ones can be encouraged. Fitting of these systems into the social context of the area in question is of extreme importance. A major research role for aquaculture institutions should be to consider the systems already in place in various locations and to help adapt them for future use.

\section{Acknowledgments}

This paper was developed as part of a symposium, entitled "The Effects of Semi-Intensive Aquaculture on Biodiversity in Nearshore and Inland Waters," held at the annual meeting of the American Fisheries Society in Seattle, in September 2011. Financial support for this symposium was partly from USAID CA/LWA No. EPP-A-00-0600012-00 through the AquaFish Collaborative Research Support Program (CRSP) and also by participating institutions. This is contribution number 1397 of the AquaFish CRSP.

\section{References}

Agostinho AA, Thomaz SM, Gomes LC (2005) Conservation of the biodiversity of Brazil's inland waters. Conservation Biology 19: 646-652.

Ahlgren MO (1998) Consumption and assimilation of salmon net pen fouling debris by the red sea cucumber
Parastichopus californicus: implications for polyculture. Journal of the World Aquaculture Society 29: 133-139.

Amend DF (1976) Prevention and control of viral diseases of salmonids. Journal of the Fisheries Research Board of Canada 33: 1059-1066.

Anders PJ (1999) Conservation aquaculture and endangered species: can objective science prevail over risk anxiety? Fisheries 23: $28-31$.

Appleford P, Lucan JS, Southgate PC (2012) General principles. In: Lucas JS, Southgate PC (eds) Aquaculture: Farming Aquatic Animals and Plants, 2nd edn, pp. 18-51. WileyBlackwell, Chichester.

Asner GP, Elmore A, Olander L, Martin RE, Harris AT (2004) Grazing systems, ecosystem responses and global change. Annual Review of Environment and Resources 29: 261-299.

Azad A, Jensen KR, Lin CK (2009) Coastal aquaculture development in Bangladesh: unsustainable and sustainable experiences. Environmental Management 44: 800-809.

Barbier EB, Cox M (2004) An economic analysis of shrimp farm expansion and mangrove conversion in Thailand. Land Economics 80: 389-407.

Bartley DM, Nguyen TTT, Halwart M, De Silva SS (2009) Use and exchange of aquatic genetic resources in aquaculture: information relevant to access and benefit sharing. Reviews in Aquaculture 1: 157-162.

Bell JD (1999) Restocking of giant clams: progress, problems and potential. In: Leber KM (ed.) Stock Enhancement and Sea Ranching, pp. 437-452. Fishing News Books, Oxford.

Bhattacharya A, Sarkar SK (2003) Impact of overexploitation of shellfish: Northeastern coast of India. AMBIO: A Journal of the Human Environment 32: 70-75.

Bondad-Reantaso MG (ed.) (2007) Assessment of Freshwater Fish Seed Resources for Sustainable Aquaculture. FAO Fisheries Technical Paper 501. FAO, Rome.

Bondad-Reantaso MG, Subasinghe RP, Arthur JR, Ogawa K, Chinabut S, Adlard R et al. (2005) Disease and health management in Asian aquaculture. Veterinary Parasitology 132: 249-272.

Boyd CE (2003) Guidelines for aquaculture effluent management at the farm-level. Aquaculture 226: 101-112.

Boyd CE, McNevin AA, Clay J, Johnson HM (2005) Certification issues for some common aquaculture species. Reviews in Fisheries Science 13: 231-279.

Brooks KM, Jones SRM (2008) Perspectives on pink salmon and sea lice: scientific evidence fails to support the extinction hypothesis. Reviews in Fisheries Science 16: 403-412.

Brooks KM, Stiernsa AR, Mahnkenb CVW, Blackburn DB (2003) Chemical and biological remediation of the benthos near Atlantic salmon farms. Aquaculture 219: 355-377.

Burridge L, Weis JS, Cabello F, Pizarro J, Bostic K (2010) Chemical use in salmon aquaculture: a review of current practices and possible environmental effects. Aquaculture 306: 7-23.

Cabello FC (2006) Heavy use of prophylactic antibiotics in aquaculture: a growing problem for human and animal 
health and for the environment. Environmental Microbiology 8: 1137-1144.

Canonico GC, Arthington A, McCrary JK, Thieme ML (2005) The effects of introduced tilapias on native biodiversity. Aquatic Conservation: Marine and Freshwater Ecosystems 15: 463-483.

Cao L, Diana JS, Keoleian GA, Lai Q (2011) Life cycle assessment of Chinese shrimp farming systems targeted for export and domestic sales. Environmental Science and Technology 45: 6531-6538.

Cicotti E (2005) Interactions between capture fisheries and aquaculture: the case of the eel (Anguilla anguilla L., 1758). In: Cataudella S, Massa F, Crosetti D (eds) Interactions between Aquaculture and Capture Fisheries: A Methodological Perspective. Studies and Reviews. General Fisheries Commission for the Mediterranean No. 78. FAO, Rome.

Clark MM (2003) Shrimp Aquaculture Brownfields: Social, Environmental, and Economic Issues Determining Rehabilitation Options (Master's thesis). University of Michigan, Ann Arbor, MI.

Cohen JE (2003) Human population: the next half century. Science 302: 1172-1175.

Costa-Pierce BA (2010) Sustainable ecological aquaculture systems: the need for a new social contract for aquaculture development. Marine Technology Society Journal 44: 88-112.

Costa-Pierce BA, Bridger CJ (2002) The role of marine aquaculture facilities as habitats and ecosystems. In: Stickney R, McVey J (eds) Responsible Marine Aquaculture, pp. 105-144. CABI Publishing Company, Wallingford.

Crawford CM, Macleod CKA, Mitchell IM (2003) Effects of shellfish farming on the benthic environment. Aquaculture 224: $117-140$.

De Silva SS, Soto D (2009) Climate change and aquaculture: potential impacts, adaptation and mitigation. In: Cochrane K, De Young C, Soto D, Bahri T (eds) Climate Change Implications for Fisheries and Aquaculture: Overview of Current Scientific Knowledge, pp. 151-212. FAO Fisheries and Aquaculture Technical Paper. No. 30. FAO, Rome.

De Silva SS, Nguyen TTT, Turchini GM, Amarasinghe US, Abery NW (2009) Alien species in aquaculture and biodiversity: a paradox in food production. AMBIO: A Journal of the Human Environment 38: 24-28.

Diana JS (2009) Aquaculture production and biodiversity conservation. BioScience 59: 27-38.

Dimitriadis C, Koutsoubas D (2011) Functional diversity and species turnover of benthic invertebrates along a local environmental gradient induced by an aquaculture unit: the contribution of species dispersal ability and rarity. Hydrobiologia 670: 307-315.

Duarte CM, Holmer M, Olsen Y, Soto D, Marbà N, Guiu J et al. (2009) Will the oceans help feed humanity? BioScience 59: 967-976.

Eglund RA (2002) The loss of native biodiversity and continuing nonindigenous species introductions in freshwater, estuarine, and wetland communities of Pearl Harbor, Oahu, Hawaiian Islands. Estuaries 25: 418-430.

Egna HS, Boyd CE (eds) (1997) Dynamics of Pond Aquaculture. CRC Press, Boca Raton, Florida.

Esselman PC (2009) Fish Communities and Conservation of Aquatic Landscapes in Northeastern Mesoamerica. (Doctoral dissertation) University of Michigan, Ann Arbor, MI.

FAO (Food and Agriculture Organization of the United Nations) (2008) Aquaculture development. 3. Genetic resource management. FAO Technical Guidelines for Responsible Fisheries. No. 5, Suppl. 3. FAO, Rome.

FAO (Food and Agriculture Organization of the United Nations) (2009) How to feed the world in 2050. FAO, Rome.

FAO (Food and Agriculture Organization of the United Nations) (2010a) The State of World Fisheries and Aquaculture. FAO, Rome.

FAO (Food and Agriculture Organization of the United Nations) (2010b) Aquaculture development. 4. Ecosystem approach to aquaculture. FAO Technical Guidelines for Responsible Fisheries 5, Supplement 4. FAO, Rome.

Flaherty M, Karnjanakesorn C (1995) Marine shrimp aquaculture and natural resources degradation in Thailand. Environmental Management 19: 27-37.

Fleming IA, Hindar K, Mjolnerod IB, Jonsson B, Balstad T, Lamberg A (2000) Lifetime success and interactions of farm salmon invading a native population. Proceedings of the Royal Society of London B 267: 1517-1523.

Foley JA, Ramankutty N, Brauman KA, Cassidy ES, Gerber JS, Johnston M et al. (2011) Solutions for a crowded planet. Nature 478: 337-342.

Ford JS, Myers RA (2008) A global assessment salmon aquaculture impacts on wild salmonids. PLoS Biology 6 (2): e33, doi: 10.1371/journal.pbio.0060033.

Gomes LC, Silva CR (2009) Impact of pond management on tambaqui, Colossoma macropomum (Cuvier), production during growth-out phase. Aquaculture Research 40: 825-832.

Gong Z, Xie P (2011) Impact of eutrophication on biodiversity of the macrozoobenthos community in a Chinese shallow lake. Journal of Freshwater Ecology 16: 171-178.

de Graaf GJ, Xuan TT (1998) Extensive shrimp farming, mangrove clearance and marine fisheries in the southern provinces of Vietnam. Mangroves and Salt Marshes 2: 159166.

Hall SJ, Dugan P, Allison EH, Andrew NL (2010) The end of the line: who is most at risk from the crisis in global fisheries? AMBIO: A Journal of the Human Environment 39: 78-80.

Halverson MA (2008) Stocking trends: a quantitative review of governmental fish stocking in the United States, 1931 to 2004. Fisheries 33: 69-75.

Hambrey J (1996) Comparative economics of land use options in mangrove. Aquaculture Asia 1 (2): 10-14.

Heck S, Béné C, Reyes-Gaskin R (2007) Investing in African fisheries: building links to the Millennium Development Goals. Fish and Fisheries 8: 211-226. 
Hiundar K, Ryman N, Utter F (1991) Genetic effects of cultured fish on natural fish populations. Canadian Journal of Fisheries and Aquatic Sciences 48: 945-957.

Hulata G (2001) Genetic manipulations in aquaculture: a review of stock improvement by classical and modern technologies. Genetics 111: 155-173.

Ireland SC, Anders PJ, Siple JT (2002) Conservation aquaculture: an adaptive approach to prevent extinction of an endangered white sturgeon population. American Fisheries Society Symposium 28: 211-222.

Jones JPG, Andriahajaina FB, Hockley N (2007) The potential of native species aquaculture to achieve conservation objectives: freshwater crayfish in Madagascar. International Journal of Biodiversity Science and Management 3: 217-222.

Kong L, Li Q (2007) Genetic comparison of cultured and wild populations of the clam Coelomactra antiquata (Spengler) in China using AFLP markers. Aquaculture 271: 152-161.

Krkosek M, Ford JS, Morton A, Lele S, Myers RA, Lewis M (2007) Declining wild salmon populations in relation to parasites from farm salmon. Science 318: 1772-1775.

Kuhlmann KH, Focken U, Coloso RM, Becker K (2009) Diurnal feeding pattern and gut content of milkfish Chanos chanos (Forsska, 1775) cultured semi-intensively during the wet and dry season in brackish ponds in the Philippines. Aquaculture Research 40: 2-12.

Lal PN (1990) Ecological economic analysis of mangrove conservation. A case study from Fiji, Mangrove Ecosystems Occasional Paper No. 6, UNDP/UNESCO Regional Mangroves Project, Hong Kong.

Lalumera GM, Calamari D, Galli P, Castiglioni S, Crosa G, Fanelli R (2004) Preliminary investigation on the environmental occurrence and effects of antibiotics used in aquaculture in Italy. Chemosphere 54: 661-668.

Lightner DV (2005) Biosecurity in shrimp farming: pathogen exclusion through use of SPF stock and routine surveillance. Journal of the World Aquaculture Society 36: 229248.

Lin CK, Yi Y (2003) Minimizing environmental impacts of freshwater aquaculture and reuse of pond effluents and mud. Aquaculture 226: 57-68.

Longdill PC, Healy TR, Black KP, Mead ST (2007) Integrated sediment habitat mapping for aquaculture zoning. Journal of Coastal Research 50: 173-179.

Lucas JS, Southgate PC (2012) Aquaculture: Farming Aquatic Animals and Plants, 2nd edn. Wiley-Blackwell, Chichester.

MacKinnon AD, Trott LA, Alongi DM, Davidson A (2002) Water column production and nutrient characteristics in mangrove creeks receiving shrimp farm effluent. Aquaculture Research 33: 55-73.

Marra J (2005) When will we tame the oceans? Nature 436: 175-176.

McCrary JK, Murphy BR, Stauffer JR Jr, Hendrix S (2005) Tilapia (Teleostei: Cichlidae) status in Nicaraguan natural waters. Environmental Biology of Fishes 78: 107-114.
Miron G, Landry T, Archambault P, Frenette B (2005) Effects of mussel culture husbandry practices on various benthic characteristics. Aquaculture 250: 138-154.

Moyle PB, Light T (1996) Biological invasions of fresh water: empirical rules and assembly theory. Biological Conservation 78: 149-161.

Mungkung R, Gheewala SH (2007) Use of life cycle assessment (LCA) to compare the environmental impacts of aquaculture and agri-food production. In: Bartley DM, Brugère $\mathrm{C}$, Soto D, Gerber $\mathrm{P}$, Harvey $\mathrm{B}$ (eds) Comparative Assessment of the Environmental Costs of Aquaculture and Other Food Production Sectors: Methods for Meaningful Comparisons, pp. 87-96. FAO Fisheries Proceedings No. 10. FAO, Rome.

Murray AG, Peeler EJ (2005) A framework for understanding the potential for emerging diseases in aquaculture. Preventive Veterinary Medicine 67: 223-235.

Naylor RL, Goldburg RJ, Mooney H, Beveridge M, Clay J, Folke C et al. (1998) Nature's subsidies to shrimp and salmon farming. Science 282: 883-884.

Naylor RL, Goldburg RJ, Primavera JH, Kautsky N, Beveridge MC, Clay J et al. (2000) Effect of aquaculture on world fish supplies. Nature 405: 1017-1024.

Neori A, Chopin T, Troell M, Buschmann AH, Kraemer GP, Halling C et al. (2004) Integrated aquaculture: rationale, evolution and state of the art emphasizing seaweed biofiltration in modern mariculture. Aquaculture 231: 361-391.

Peterson MS, Slack WT, Woodley CM (2005) The occurrence of non-indigenous Nile tilapia, Oreochromis niloticus (Linnaeus) in coastal Mississippi, USA: ties to aquaculture and thermal effluent. Wetlands 25: 112-121.

Piedrahita RH (2003) Reducing the potential environmental impact of tank aquaculture effluents through intensification and recirculation. Aquaculture 226: 35-44.

Pillay TVR (1993) Aquaculture: Principles and Practices. Fishing News Books, London, UK.

Pollnac RB, Pomeroy RS, Harkes IHT (2001) Fishery policy and job satisfaction in three southeast Asian fisheries. Ocean and Coastal Management 44: 531-544.

Pomeroy RS, Parks JE, Balboa CM (2006a) Farming the reef: is aquaculture a solution for reducing fishing pressure on coral reefs? Marine Policy 30: 111-130.

Pomeroy RS, Ratner BD, Hall SJ, Pimoljinda J, Vivekanandan V (2006b) Coping with disaster: rehabilitating coastal livelihoods and communities. Marine Policy 30: 786-793.

Pomeroy R, Parks J, Pollnac R, Campson T, Genio E, Marlessy C et al. (2007) Fish wars: conflict and collaboration in fisheries management in Southeast Asia. Marine Policy 31: 645-656.

Ponzoni RW, Hamzah A, Saadiah T, Kamaruzzaman N (2005) Genetic parameters and response to selection for live weight in the GIFT strain of Nile tilapia (Oreochromis niloticus). Aquaculture 247: 203-210.

Primavera JH (2006) Overcoming the impacts of aquaculture on the coastal zone. Ocean and Coastal Management 49: $531-545$. 
Rabalais NN, Turner RE, Wiseman WJ Jr (2002) Gulf of Mexico hypoxia, aka. 'The Dead Zone'. Annual Review of Ecology and Systematics 33: 235-263.

Radulovich R (2011) Massive freshwater gains from producing food at sea. Water Policy 13: 547-554.

Rice JC, Garcia SM (2011) Fisheries, food security, climate change, and biodiversity characteristics of the sector and perspectives on emerging issues. ICES Journal of Marine Science 68: 1343-1353.

Rogers E (1995) Diffusion of Innovations, 4th edn. Free Press, New York

Schwantes VS, Diana JS, Yi Y (2009) Social, economic, and production characteristics of giant river prawn Macrobrachium rosenbergii culture in Thailand. Aquaculture 287: 120-127.

Sequeira A, Ferreira JG, Hawkins AJH, Nobre A, Lourenço P, Zhang XL et al. (2008) Trade-offs between shellfish aquaculture and benthic biodiversity: a modelling approach for sustainable management. Aquaculture 274: 313-328.

Singh K, Dey MM (2010) Sources of family income and their effects on family income inequality: a study of fish farmers in Tripura, India. Food Security 2: 359-365.

Smil V (2002) Nitrogen and food production: proteins for human diets. AMBIO: A Journal of the Human Environment 31: 126-131.

Stickney RR (1993) Culture of Nonsalmonid Freshwater Fishes CRS Press, Boca Raton, FL

Tilman D, Fargione J, Wolff B, D’Antonio C, Dobson A, Howarth R et al. (2009) Forecasting agriculturally driven global environmental change. Science 292: 281-284.

Troell M, Joyce A, Chopin T, Neori A, Buschmann AH, Fang J-G (2009) Ecological engineering in aquaculture - potential for integrated multi-trophic aquaculture (IMTA) in marine offshore systems. Aquaculture 297: 1-9.

Trott LA, Alongi DM (2000) The impact of shrimp pond effluent on water quality and phytoplankton biomass in a tropical mangrove estuary. Marine Pollution Bulletin 40: 947951.

Turner RE (1977) Intertidal vegetation and commercial yields of Penaeid shrimp. Transactions of the American Fisheries Society 106: 401-416.

Tyedmers P (2001) Energy consumed by North Atlantic fisheries. In: Zeller R, Watson R, Pauly D (eds) Fisheries Impacts on North Atlantic Ecosystems: Catch, Effort, and National/ Regional Data Sets, Vol. 9, pp. 12-34. Fisheries Centre Research Reports, University of British Columbia, Vancouver.

Verdegem MCJ, Bosma RH (2009) Water withdrawal for brackish and inland aquaculture, and options to produce more fish in ponds with present water use. Water Policy 11 (Suppl 1): 52-68.

Verdegem MCJ, Bosma RH, Verreth JAJ (2006) Reducing water use for animal production through aquaculture. International Journal of Water Resources Development 22: 101113.

Xiao Y, Ferreira JG, Bricker SB, Nunes JP, Zhu M, Zhang X (2007) Trophic assessment in Chinese coastal systems review of methods and application to the Changjiang (Yangtze) estuary and Jiaozhou bay. Estuaries and Coasts 30: 901-918.

Yang Y-F, Fei X-G, Song J-M, Hu H-Y, Wang G-C, Chung IK (2006) Growth of Gracilaria lemaneiformis under different cultivation conditions and its effects on nutrient removal in Chinese coastal waters. Aquaculture 254: 248-255.

Youngson AF, Dosdat A, Saroglia M, Jordan WC (2001) Genetic interactions between marine finfish species in European aquaculture and wild conspecifics. Journal of Applied Ichthyology 17: 153-162.

Zhou Y, Yang H, Hu H, Liu Y, Mao Y, Zhou $\mathrm{H}$ et al. (2006) Bioremediation potential of the macroalga Gracilaria lemaneiformis (Rhodophyta) integrated into fed fish culture in coastal waters of north China. Aquaculture 252: 264-276. 